Annals of Warsaw University of Life Sciences - SGGW

Land Reclamation No 46 (4), 2014: 301-307

(Ann. Warsaw Univ. Life Sci. - SGGW, Land Reclam. 46 (4), 2014)

\title{
Suction controlled triaxial testing of unsaturated medium sand and sandy clay
}

\author{
ZDZISŁAW SKUTNIK, MARCIN BILINIAK \\ Department of Geotechnical Engineering, Warsaw University of Life Sciences - SGGW
}

\begin{abstract}
Suction controlled triaxial testing of unsaturated medium sand and sandy clay. This paper presents the results of the triaxial tests performed on medium sand and sandy clay samples. The shear strength and deformation characteristics from consolidated drained (CD) tests performed in a controlled saturation state were determined. The study was conducted in a modern apparatus for triaxial testing of unsaturated samples. Test specimens with a diameter of $70 \mathrm{~mm}$ and height of $140 \mathrm{~mm}$ were prepared by compaction in a laboratory in a special form. The main aim of this study was to investigate the effect of matric suction on the shear strength and deformation characteristic of medium sand and sandy clay. The axis translation technique was used to apply matric suction to soil specimens.
\end{abstract}

Key words: unsaturated soil, matric suction, shear strength, deformation characteristics, triaxial testing

\section{INTRODUCTION}

Shear strength and deformation characteristics are ones of the fundamental properties of soils (Alonso and Gens, 1991). It has been required for the design of the numerous geotechnical and environmental structures, such as foundations, earth dams, retaining walls, reservoirs and others. A geotechnical design without considering unsaturated soil condition is much easier but it makes the increasing costs associated with con- struction. The contribution of matric suction to shear strength or stiffness of soils generally results in increasing of bearing capacity and decreasing of settlements (Alonso et al., 1990, Fredlund and Rahardjo, 1990, 1993, Lu and Likos, 2004, Skutnik, 2011).

The triaxial test is one of the most versatile and widely performed laboratory tests, allowing for the soil shear strength and stiffness estimation for use in the geotechnical design (Bishop and Blight, 1963, Head, 1982, Lipiński and Wdowska, 2011). Ability to control specimen drainage, measurement of pore pressure or suction apply, allowing to the soil response to be observed under conditions that may approximate those in situ. Suction controlled tests are commonly performed using a triaxial apparatus where soil suction can be controlled using the axis translation technique (Toll, 1990, Romero, 1999). The suction is usually kept constant during the application of shear stresses. In suction controlled drained tests the water and the air are allowed to flow in and out of the specimen in order to maintain the applied matric suction. This kind of test can be used in order to determine both 
the shear strength and deformation characteristics of unsaturated soils.

The main objective of this study was to evaluate the effect of the matric suction on the deformation characteristics of unsaturated cohesionless and cohesive soils. The another objective was to perform, drained triaxial test to evaluate the shear strength parameters for fully saturated and unsaturated state of medium sand soil samples.

\section{SOIL PROPERTIES AND TESTING PROCEDURES}

\section{Tested soils and sample preparation}

The soils used in the tests were sandy clay and medium sand. The grain size distribution curves of tested soils are presented in Figure 1. The experiments were carried out on a laboratory compacted soil samples. The basic properties of tested soil samples are given in Table 1. A sample preparation technique was conducted as follows. The medium sand samples with a water content about $10 \%$ were statically compacted

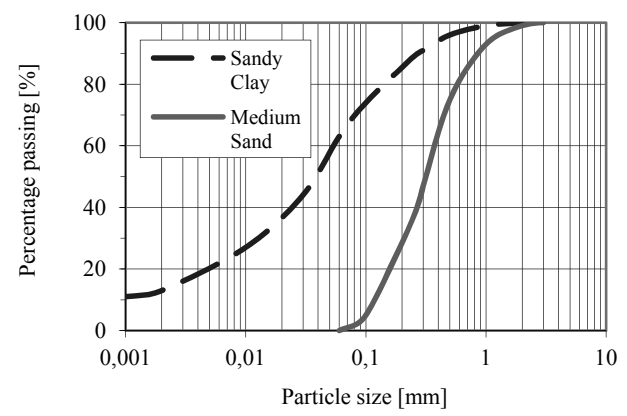

FIGURE 1. The grain size distribution curves of tested soils
TABLE 1. Basic properties of tested soils

\begin{tabular}{|l|c|c|c|c|c|}
\hline \multirow{2}{*}{ Soil type } & \multirow{2}{*}{$\begin{array}{l}\text { Sample } \\
\text { Identity }\end{array}$} & $w$ & $\rho$ & $\rho_{d}$ & $\rho_{s}$ \\
\cline { 3 - 6 } & & \multicolumn{3}{|c|}{$\mathrm{t} / \mathrm{m}^{3}$} \\
\hline $\begin{array}{l}\text { Medium } \\
\text { sand }\end{array}$ & TRX 0 & 9.8 & 1.888 & 1.719 & 2.65 \\
\hline $\begin{array}{l}\text { Medium } \\
\text { sand }\end{array}$ & TRX 1 & 6.5 & 1.831 & 1.719 & 2.65 \\
\hline $\begin{array}{l}\text { Medium } \\
\text { sand }\end{array}$ & TRX 2 & 9.1 & 1.951 & 1.788 & 2.65 \\
\hline Sandy clay & TRX 3 & 11.5 & 2.217 & 1.990 & 2.67 \\
\hline Sandy clay & TRX 4 & 14.4 & 2.188 & 1.920 & 2.67 \\
\hline
\end{tabular}

to a dry density value of approximately $1.75 \mathrm{t} / \mathrm{m}^{3}$. The compaction was carried out in a suitable former consisting of a steel ring and a three-split mold of $70 \mathrm{~mm}$ diameter and $140 \mathrm{~mm}$ height. The sand was dropped into layers inside a membrane fitted inside the mold. After the specimen had been leveled, capped and sealed, suction was applied to give sufficient strength and make the sample self-supporting. Following this initial preparation the specimens were consolidated and sheared according to the assumed procedure. The sandy clay samples were prepared by compaction with normal Proctor energy with a water content close to the optimum water content, which is equal to $13.5 \%$.

\section{Testing equipment and procedure}

All the tests were conducted in the Water Center Laboratory of WULS-SGGW using a triaxial automated system capable of testing soils in unsaturated state by axis translation technique. The system consists on the following main components (Fig. 2): triaxial cell, load frame, cell and pore water pressure/volume 


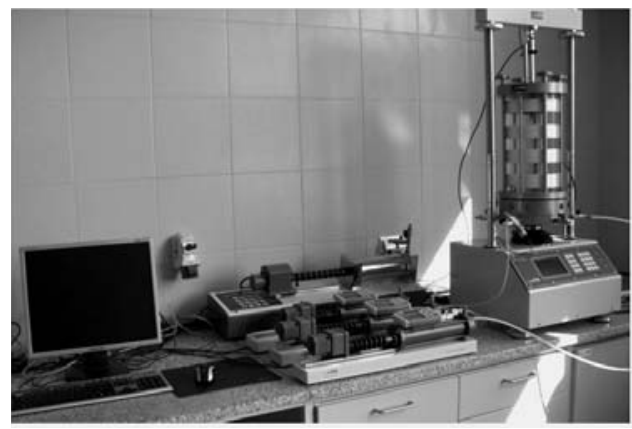

FIGURE 2. The view of triaxial automated system for unsaturated soil testing

controllers, pore air pressure/volume controller, load cell, axial displacement transducer, control and data acquisition unit and software.

During the consolidation stage stresses were applied and soil was allowed to come to equilibrium. The matric suction was archived by applying axis translation technique. Thereafter, with the confining pressure being held at constant value after finishing the consolidation stage, the samples were sheared under strain controlled conditions. During this stage the air and the water were allowed to move from the soil sample under regulated (constant) pressure. The failure criteria was assumed as a maximum of deviator stress.

\section{TESTING PROGRAMME}

The experimental programme consisted of three triaxial consolidated drained (CD) tests with matric suction equal to 0,60 and $200 \mathrm{kPa}$ performed on medium sand samples and two traixial consolidated drained (CD) tests with matric suction equal to 60 and $200 \mathrm{kPa}$ for the sandy clay samples. The confining net pressure was equal to 50 and $200 \mathrm{kPa}$. The initial stress state variables of each soil sample during a consolidation stage and shearing it has been stated in Table 2 . All the samples were sheared by applying an axial strain to the specimen. Response of the specimen was monitored during the whole shear stage by data acquisition system.

TABLE 2. Applied pressure and matric suction

\begin{tabular}{|c|c|c|c|c|c|c|}
\hline \multirow[t]{2}{*}{ Soil type } & \multirow[t]{2}{*}{$\begin{array}{l}\text { Sample } \\
\text { Identity }\end{array}$} & $\sigma_{3}$ & $u_{a}$ & $u_{w}$ & $\begin{array}{l}z^{3} \\
1 \\
z^{2} \\
\| \\
n\end{array}$ & $\begin{array}{l}2^{0} \\
1 \\
0^{m} \\
\|^{n} \\
0^{\frac{\vec{g}}{m}}\end{array}$ \\
\hline & & \multicolumn{5}{|c|}{$\mathrm{kPa}$} \\
\hline $\begin{array}{l}\text { Medium } \\
\text { sand }\end{array}$ & TRX 0 & 100 & - & 50 & - & - \\
\hline $\begin{array}{l}\text { Medium } \\
\text { sand }\end{array}$ & TRX 1 & 160 & 110 & 50 & 60 & 50 \\
\hline $\begin{array}{l}\text { Medium } \\
\text { sand }\end{array}$ & TRX 2 & 300 & 250 & 50 & 200 & 50 \\
\hline $\begin{array}{l}\text { Sandy } \\
\text { clay }\end{array}$ & TRX 3 & 160 & 110 & 50 & 60 & 50 \\
\hline $\begin{array}{l}\text { Sandy } \\
\text { clay }\end{array}$ & TRX 4 & 300 & 250 & 50 & 200 & 50 \\
\hline
\end{tabular}

The main objective of this tests was to determine the deformation characteristics of the medium sand and sandy clay samples to estimate the effect of the matric suction on the value of deformation modulus. The test results, deviator stress-axial strain curves for medium sand at a matric suctions equal to 0,60 and $200 \mathrm{kPa}$ are shown in Figure 3. For the same net confining pressure and a matric suction (except $0 \mathrm{kPa}$ ) as for the medium sand the deviator stress-axial strain characteristics for sandy clay are presented in Figure 4. 


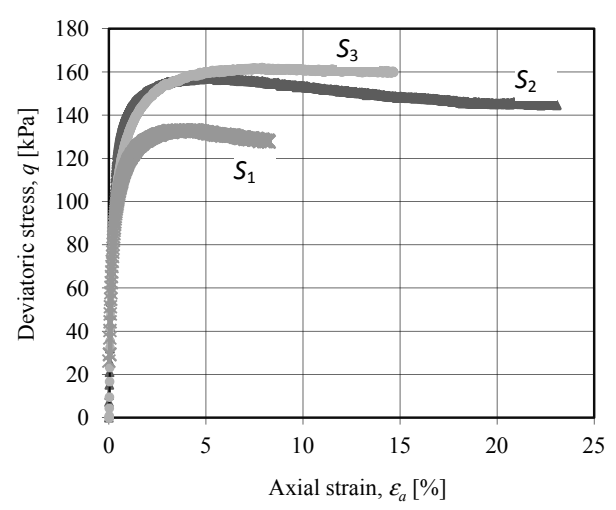

FIGURE 3. Stress-strain curves for medium sand samples under the $50 \mathrm{kPa}$ confining net pressure at various suction, $S_{1}=0 \mathrm{kPa}, S_{2}=60 \mathrm{kPa}$ and $S_{3}=200 \mathrm{kPa}$

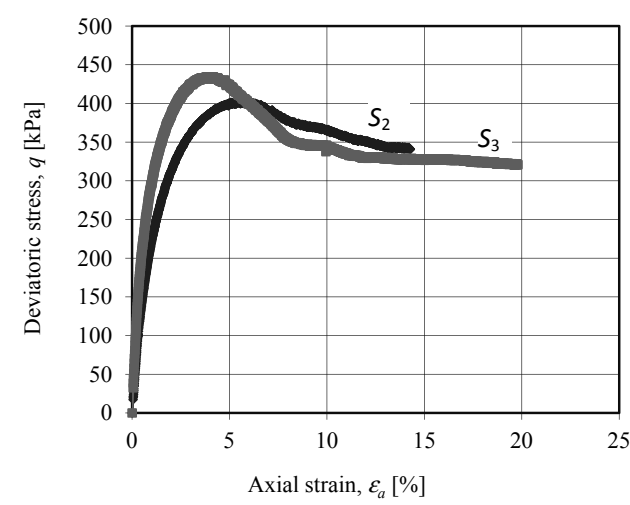

FIGURE 4. Stress-strain curves for sandy clay samples under the $50 \mathrm{kPa}$ confining net pressure at various suction, $S_{2}=60 \mathrm{kPa}$ and $S_{3}=200 \mathrm{kPa}$

The secant modulus of deformation, which is defined as the ratio of deviator stress value to the corresponding axial strain, has been chosen for estimation of the effect of suction on soil stiffness. The selection of modulus of soil for engineering applications depends on the practical problem it has to be solved. There are many recommendations in literature.
The values of secant modulus of deformation were determined based on stress-strain characteristics shown in Figures 3 and 4 . In Figure 5a variability of secant modulus of deformation value for a given matric suction value for the medium sand samples is presented.

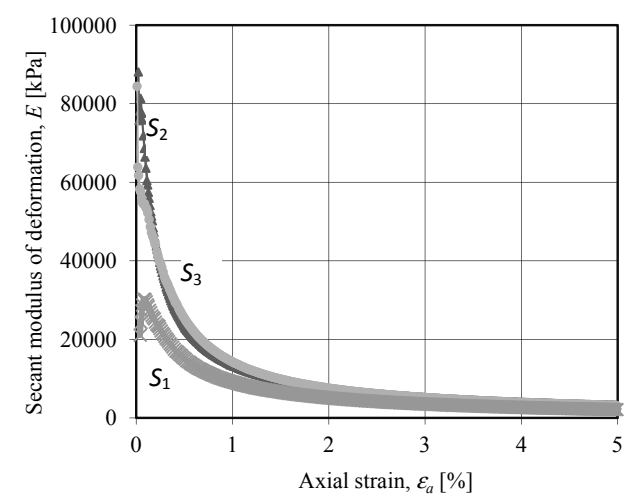

FIGURE 5. Variability of secant modulus of deformation value with matric suction, $S_{1}=0 \mathrm{kPa}$, $S_{2}=60 \mathrm{kPa}$ and $S_{3}=200 \mathrm{kPa}$ for medium sand samples

Changes of the secant modulus of deformation values for sandy clay samples are shown in Figure 6. It can be seen that for the fully saturated medium sand sample stiffness is lower than for the samples for which the suction was induced by axis translation technique up to 60 or $200 \mathrm{kPa}$. Figure 6 indicates that the stiffness of sandy clay samples for suction $200 \mathrm{kPa}$ is much higher than for the sample for which suction was equal to $60 \mathrm{kPa}$.

The another goal of CD tests performed on medium sand samples was to investigate the effect of matric suction on the shear strength parameters, angle of internal friction and cohesion. 


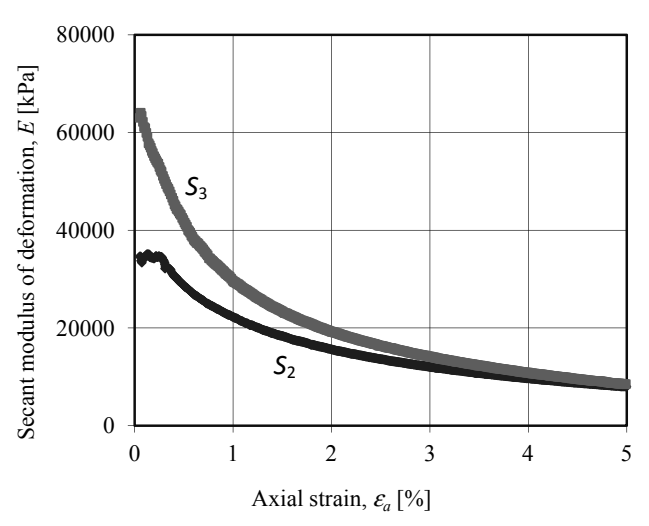

FIGURE 6. Variability of secant modulus of deformation value with matric suction, $S_{2}=60 \mathrm{kPa}$ and $S_{3}=200 \mathrm{kPa}$ for sandy clay samples

In Figures 7 and 8 the test results are presented for samples sheared without any suction samples were fully saturated and confining stress was equal to 50 and $200 \mathrm{kPa}$. In Figures 9 and 10 the tests results for samples sheared with suction $200 \mathrm{kPa}$ for the confining net stress equal to 50 and $200 \mathrm{kPa}$ were shown. In both cases the determined angle of internal friction is near the same and it changes in the range of $33.4^{\circ}$ and $34.7^{\circ}$. For tests carried out with the higher

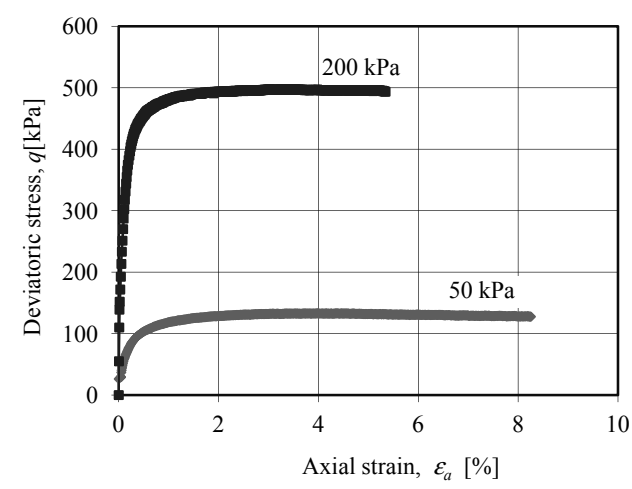

FIGURE 7. Stress-strain curves for samples of medium sand at various confining net stress and suction equal to $0 \mathrm{kPa}$

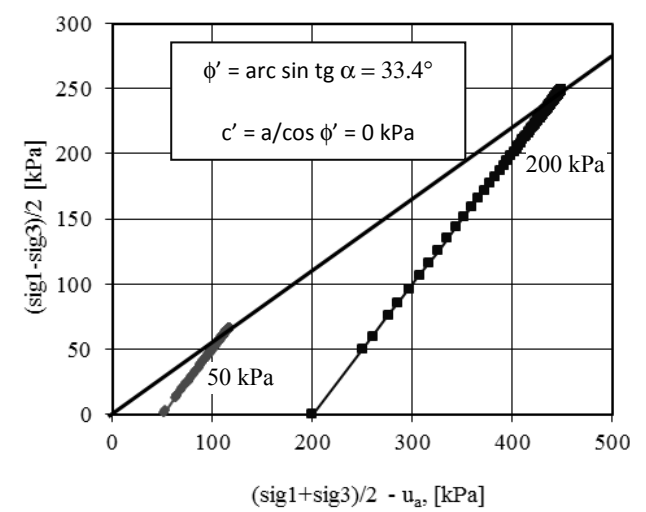

FIGURE 8. Stress path for samples of medium sand at various confining net stress and suction equal to $0 \mathrm{kPa}$

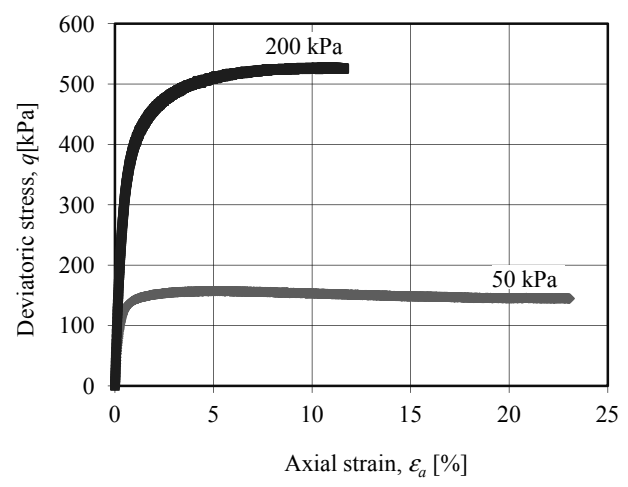

FIGURE 9. Stress-strain curves for samples of medium sand at various confining net stress and suction equal to $200 \mathrm{kPa}$

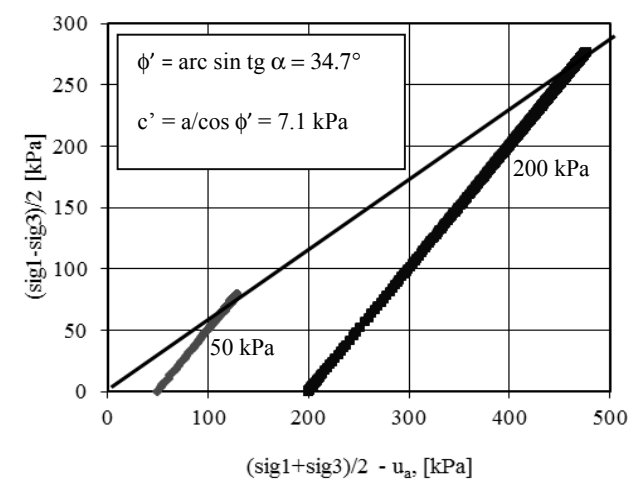

FIGURE 10. Stress path for samples of medium sand at various confining net stress and suction equal to $200 \mathrm{kPa}$ 
value of suction, equal to $200 \mathrm{kPa}$, it was noticed the presence of apparent cohesion which is not high and is equal to $7.4 \mathrm{kPa}$.

\section{CONCLUSIONS}

The results obtained from a series of triaxial tests performed on medium sand and sandy clay samples confirmed the influence of matrix suction on stiffness and shear strength.

The stiffness of the sandy clay samples is greater for the higher value of suction while for the medium sand samples the stiffness does not depend on suction value, but is higher than for fully saturated samples.

The results of triaxial tests showed that unsaturated medium sand could attain apparent cohesion.

Because the results shown in this paper are based on a few tests, it should be accumulate more data to verify these tendency.

\section{REFERENCES}

ALONSO E.E., GENS A. 1991: A framework for the behavior of unsaturated expansive clays. Canadian Geotechnical Journal 29: 1013-1032.

ALONSO E.E., GENS A., JOSA A. 1990: A constitutive model for partially saturated soils. Géotechnique 40 (3): 405-429.

BISHOPA.W., BLIGHT G.E. 1963: Some aspects of effective stress in saturated and partly saturated soils. Géotechnique 13, 3: 177-197.

FREDLUND D.G., RAHARDJO H. 1990: Stress state variables for unsaturated soils. Canadian Geotechnical Journal 15, 3: 313-321.

FREDLUND D.G., RAHARDJO H. 1993: Soil mechanics for unsaturated soils. John Wiley \& Sons, New York.
HEAD K.H. 1982: Manual of Soil Laboratory Testing. Vol. 3. John Wiley, New York - Chichester.

LIPIŃSKI M.J., WDOWSKA M.K. 2011: A stress history and strain dependent stiffness of overconsolidated cohesive soil, Annals of Warsaw University of Life Sciences - SGGW. Land Reclamation 43 (2): 207-216.

Lu N., LIKOS W. 2004: Unsaturated soil mechanics. John Wiley and Sons, New York.

ROMERO E. 1999: Characterization and thermo-hydro-mechanical behaviour of unsaturated Boom clay: an experimental study. Doctoral Thesis, Universitat Politecnica de Catalunya, Barcelona.

SKUTNIK Z. 2011: Assessment of permeability and pore water pressure in Warsaw clays based on in situ measurements. Annals of Warsaw University of Life Sciences - SGGW. Land Reclamation 43 (2): 185-192.

TOLL D.G. 1990: A framework for unsaturated soil behaviour. Géotechnique 40 (1): 31-44.

Streszczenie: Badania nienasyconych próbek piasku średniego i gliny piaszczystej $w$ aparacie trójosiowego ściskania z kontrolowanym ciśnieniem ssania. $\mathrm{W}$ artykule przedstawiono wyniki badań próbek piasku średniego i gliny piaszczystej przeprowadzonych $\mathrm{w}$ aparacie trójosiowego ściskania. Na podstawie badań wykonanych metodą z konsolidacją i odpływem (CD) oraz kontrolowanym stanem nasycenia wyznaczono charakterystyki odkształceniowe i wytrzymałościowe. Badania zostały przeprowadzone w nowoczesnym aparacie trójosiowego ściskania do badania próbek nienasyconych. Próbki do badań o średnicy $70 \mathrm{~mm}$ i wysokości $140 \mathrm{~mm}$ przygotowano w laboratorium, zagęszczając grunty w specjalnej formie. Celem badania było określenie wpływu ciśnienia ssania na parametry wytrzymałościowe i charakterystyki odkształceniowe piasku średniego i gliny piaszczystej. Do wytworzenia ssania w próbce gruntu zastosowano technikę translacji osi.

Stowa kluczowe: grunt nienasycony, ssanie macierzyste, wytrzymałość na ścinanie, charakterystyki odkształceniowe, badanie trójosiowe 
MS. received July 2014

\author{
Authors' address: \\ Zdzisław Skutnik \\ Katedra Geoinżynierii \\ Wydział Budownictwa i Inżynierii Środowiska \\ SGGW \\ ul. Nowoursynowska, 02-787 Warszawa \\ Poland \\ e-mail: zdzislaw_skutnik@sggw.pl
}

